\title{
Percutaneous Lumbar Laser Disc Decompression: A Systematic Review of Current Evidence
}

Vijay Singh, MD¹, Laxmaiah Manchikanti, MD², Ramsin M. Benyamin, MD², Standiford Helm, MD, and Joshua A. Hirsch, MD

From: ${ }^{1}$ Pain Diagnostics Associates, Niagara, WI; ${ }^{2}$ Pain Management Center of Paducah, Paducah, KY; ${ }^{3}$ Millennium Pain Center, Bloomington, IL; 4Pacific Coast Pain Management Center, Laguna Hills, CA; and ${ }^{5}$ Massachusetts General Hospital and Harvard Medical School, Boston, MA

Dr. Singh is Medical Director of Pain Diagnostics Associates, Niagara, WI.

Dr. Manchikanti is Medical Director of the Pain Management Center of Paducah, Paducah, KY.

Dr. Benyamin is the Medical Director, Millennium Pain Center,

Bloomington, IL, and Clinical Assistant Professor of Surgery, College of Medicine, University of Illinois, Urbana-Champaign, IL. Dr. Helm is Medical Director,

Pacific Coast Pain Management Center, Laguna Hills, CA Dr. Hirsch is Chief of Minimally Invasive Spine Surgery, Depts. of Radiology and Neurosurgery, Massachusetts General Hospital and Assistant Professor of Radiology, Harvard Medical School, Boston, MA.

Address correspondence: Vijay Singh, MD

W809o Millie Hill Estates Dr. Iron Mountain, MI 49801-6722 E-mail: vj@wmpnet.net

Disclaimer: There was no external funding in the preparation of this manuscript. Conflict of interest: None.

Manuscript received: 04/15/2009 Accepted for publication: 05/03/2009

Free full manuscript: www.painphysicianjournal.com
Background: Since the descriptions by Mixter and Barr of open surgical treatment for rupture of the intervertebral disc in 1934, open surgical procedures have become a common practice. Disc herniations have been reported as being contained and non-contained. The results of open surgical discectomy for contained disc herniation have been poor. Consequently, several alternative techniques have been developed which are minimally invasive including percutaneous laser disc decompression.

Study Design: A systematic review of the literature.

Objective: The objective of this systematic review is to evaluate the clinical effectiveness of percutaneous laser discectomy in managing radicular pain secondary to contained disc herniation.

Methods: A comprehensive evaluation of the literature relating to mechanical disc decompression was performed. The literature was evaluated according to Cochrane review criteria for randomized controlled trials (RCTs), and Agency for Healthcare Research and Quality (AHRQ) criteria was utilized for observational studies.

A literature search was conducted by using only the English language literature through PubMed, EMBASE, the Cochrane library, systematic reviews, and cross references from reviews and systematic reviews.

The level of evidence was classified as Level I, II, or III with 3 subcategories in Level II based on the quality of evidence developed by the United States Preventive Services Task Force (USPSTF).

Outcome Measures: Pain relief was the primary outcome measure. Other outcome measures were functional improvement, improvement of psychological status, opioid intake, and return to work

Short-term effectiveness was defined as one year or less, whereas, long-term effectiveness was defined as greater than one year.

Results: Based on USPSTF criteria the indicated level of evidence for percutaneous lumbar laser discectomy (PLLD) is II-2 for short- and long-term relief.

Limitations: Even though laser discectomy has been in utilization for a number of years and numerous procedures have been performed there continues to be a paucity of literature of randomized clinical trials.

Conclusion: This systematic review illustrates Level II-2 evidence for percutaneous laser disc decompression which is equivalent to automated percutaneous lumbar disc decompression.

Key words: Intervertebral disc disease, chronic low back pain, disc herniation, disc protrusion, radiculitis, contained disc herniation, mechanical disc decompression, percutaneous lumbar laser discectomy, laser assisted spinal endoscopy

Pain Physician 2009; 12:573-588 


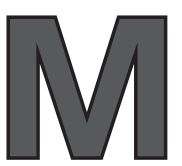

ixter and Barr (1) reported an open surgical treatment for rupture of the intervertebral disc in 1934. Since then numerous surgeries have been performed (2-5). Disc displacement may occur in many forms with disc prolapse, protrusion, or herniation with nerve root irritation, accounting for less than $5 \%$ of all low back problems (5). Disc herniation has been reported as contained and non-contained. The main objective of surgical treatment of a disc prolapse, protrusion, or extrusion is the relief of nerve root compression by removing the herniated nuclear material. Despite the prevalence of open discectomy, in many ways surgical treatment of lower lumbar disease has never been put to rigorous scientific study. Carragee et al (6) studied clinical outcomes after lumbar discectomy for sciatica and found a number of noteworthy results. These investigators demonstrated that patients in the no fragment-contained group did very poorly with $38 \%$ having recurrent or persistent sciatica, and the standard outcomes scores were less improved compared with those in other groups. In contrast, patients in the fragment-fissure group, who had disc fragments and small anular defects, had the best overall outcomes and the lowest rates of reherniation (1\%) and reoperation $(1 \%)$. Further, patients in the fragment-contained group had a $10 \%$ rate of reherniation and a $5 \%$ rate of reoperation and patients in the fragment-defect group with extruded fragments and massive posterior anular loss had a $27 \%$ rate of reherniation and $21 \%$ rate of reoperation. Similar to Carragee et al, Dewing et al (7) showed that patients with sequestered or extruded lumbar disc herniations had significantly better outcomes than did those contained herniations. Thus, it is crucial not only that patients are selected appropriately, but also that the technique is properly chosen. Consequently, several alternative techniques have been developed which are minimally invasive. Percutaneous laser disc decompression (PLDD) is one of the so-called "minimally invasive" treatment modalities for contained lumbar disc herniation (8).

The treatment is performed percutaneously, so morbidity is expected to be lower and the convalescence period is postulated to be shorter than for conventional surgery. However, considerable skepticism exists about this technology. Opponents usually dismiss PLDD as being an experimental treatment with unproven efficacy, whereas those advocating for the use of PLDD present contrary evidence with regards to its effectiveness (8). The paucity of literature on the subject without randomized controlled trials (RCTs) is a major source of skepticism. Schenk et al (8) in review of the literature on percutaneous lumbar laser disc decompression concluded that all trials were case series, with a relatively low strength of evidence. They concluded that despite the fact that PLDD has been around for almost 20 years, scientific proof of its efficacy still remains relatively poor, though the potential medical and economic benefits of PLDD are too high to justify discarding it as experimental or ineffective on the sole basis of insufficient scientific proof.

Gibson and Waddell (5) in the Cochrane Collaboration review presented the results from 40 RCTs and 2 quasi-randomized controlled trials (QRCTs) of surgical interventions for lumbar disc prolapse. This review indicated that the place for other forms of discectomy other than traditional open discectomy is unresolved. Trials of percutaneous discectomy and laser discectomy suggest that clinical outcomes following treatment are at best fair and certainly worse than after microdiscectomy, although the importance of patient selection is acknowledged. Gibson and Waddell (5) concluded that discectomy provides faster relief from the acute attack of sciatica, although any positive or negative effects on the long-term natural history of the underlying disc disease are unclear.

In a technology assessment report (9), no randomized published studies of PLDD were identified for the analysis. However, the majority of the observational studies evaluating percutaneous laser discectomy showed positive evidence. Boswell et al (10) in evidence-based guidelines of spinal interventional techniques showed that evidence was moderate for shortterm and limited for long-term relief for automated and laser discectomy.

Due to the fact that the treatment principle of PLDD is based on the concept of the invertebral disc being a closed hydraulic system, only contained herniations can be expected to respond to reduction of intradiscal pressure (8). Consequently, the presence of disc extrusion or sequestered herniation are considered to be exclusion criteria for PLDD. Further, patients with narrowed intervertebral disc space or obstructive vertebral abnormalities, and severe neurologic symptoms, such as cauda equina syndrome, severe paresis, or other conditions that require acute surgical intervention are not generally considered candidates for PLDD.

This systematic review was undertaken to evaluate the current evidence of percutaneous mechanical disc decompression with lumbar laser discectomy. Due to 
the experience of previous systematic reviews $(5,9)$ with lack of randomized trials, this systematic review also focused on observational studies to improve the generalizability and applicability in clinical practice (11-15).

\section{Methods}

\section{Literature Search}

Databases reviewed were PubMed, EMBASE, the Cochrane Library, and the Database of Reviews of Effectiveness (DARE). Bibliographies of reviewed papers were also examined. In addition, authors known to be active in the field were contacted. The time frame covered was 1966 to January 2009.

Inclusion criteria were:

1. Lumbar disc related pain of at least 3 months duration,

2. Treatment with percutaneous laser disc decompression.

3. Minimum of 12-month follow-up.

4. At least 50 patients included in observational studies.

Search terms included intervertebral disc, degenerative disc disease, disc herniation, disc protrusion, disc extrusion, disc prolapse, disc displacement, radiculitis, percutaneous laser discectomy, percutaneous laser disc decompression, and laser nuclear decompression.

Only articles in English or with English abstracts, systematic reviews, RCTs, and observational studies were reviewed by 2 reviewers. Discrepancies in ratings were resolved by adjudication by a third reviewer. If there was a conflict of interest with the reviewed manuscripts such as authorship or any other type of conflict, the involved authors did not review the manuscripts for quality assessment, clinical relevance, evidence synthesis, or grading of evidence.

\section{Methodologic Quality Assessment}

The method of quality assessment was a function of the type of study. For RCTs, the Cochrane review criteria were used (16). Assessment of study quality for observational studies was done according to the Agency for Healthcare Research and Quality (AHRQ) criteria (17). Both the RCTs and observational forms provide a maximum of 100 points; only studies with scores of over 50 points were included. Consensusbased weighted scoring developed by the guidelines committee of the American Society of Interventional Pain Physicians (ASIPP) was utilized. The same scoring system has been used in multiple previous evaluations (18-34).

\section{Outcome Measures}

Pain relief was the primary outcome measure. Other outcome measures were functional improvement, improvement of psychological status, and return to work.

A decrease of either 2 points or $30 \%$ of pain scores provides a useful benchmark of clinical importance to assess effectiveness $(35,36)$. Similarly, a $10 \%$ improvement in functioning outcomes provides an accepted benchmark of clinically useful benefit (37). However, in interventional pain management settings, a significant improvement has been defined as $50 \%$ or more relief, while significant improvement in disability has been defined as a $40 \%$ or more decrease in disability scores in multiple publications (13-15,38-44).

Significant pain relief $(\geq 50 \%)$ of short-term $(\leq 12$ months) and long-term (> 12 months) was the primary outcome measure. Secondary outcomes included functional or psychological improvement, improvement in work status, and complications.

\section{Analysis of Evidence}

Level of evidence was determined based on the United States Preventive Services Task Force (USPSTF) criteria using 5 levels of evidence, ranging from Level I to III with 3 subcategories in Level II, as illustrated in Table 1 (45).

Table 1. Quality of evidence developed by USPSTF.

\begin{tabular}{|c|l||}
\hline I: & Evidence obtained from at least one properly randomized controlled trial \\
\hline II-1: & Evidence obtained from well-designed controlled trials without randomization \\
\hline II-2: & Evidence obtained from well-designed cohort or case-control analytic studies, preferably from more than one center or research group \\
\hline II-3: & $\begin{array}{l}\text { Evidence obtained from multiple time series with or without the intervention. Dramatic results in uncontrolled experiments (such } \\
\text { as the results of the introduction of penicillin treatment in the 1940s) could also be regarded as this type of evidence }\end{array}$ \\
\hline III: & Opinions of respected authorities, based on clinical experience descriptive studies and case reports or reports of expert committees \\
\hline \hline
\end{tabular}

Adapted from the U.S. Preventive Services Task Force (USPSTF) (45). 


\section{Recommendations}

Recommendations for effectiveness were made according to Guyatt et al's criteria (46) (Table 2).

\section{Results}

The results of the literature search for percutaneous laser disc decompression are illustrated in Fig. 1. A total of 33 articles (47-79) were located in the literature search. There were no RCTs.

\section{Methodologic Quality Assessment}

There were no randomized trials identified for analysis. However, multiple observational studies were identified describing mechanical disc decompression with percutaneous laser disc decompression.

Multiple studies $(47-49,51,54,56,60,66,68-70,72-$ 79) as shown in Table 3 were excluded for various reasons as described. Overall 14 observational studies met the inclusion criteria for methodologic quality assessment (17). Methodologic quality scores are described in Table 4, ranging from 30 to 80 . Of these, 10 studies scored 50 or above $(52,53,57,58,61,62,64,65,67,71$ ), meeting the percutaneous laser disc decompression methodologic quality assessment criteria for evidence synthesis.

\section{Study Characteristics}

Table 5 illustrates the results of percutaneous disc decompression with laser-assisted disc removal. All the studies showed positive results. Results varied from satisfactory improvement in $56 \%$ of the patients to $87 \%$ of the patients. In the 10 reports included in the evidence synthesis, 2,447 patients were studied with positive outcome in 1,774 patients or $72 \%$.

Knight and Goswami (64) sought to determine the outcome of laser disc decompression in the man-

Table 2. Grading recommendations.

\begin{tabular}{|c|c|c|c|}
\hline $\begin{array}{c}\text { Grade of } \\
\text { Recommendation/ } \\
\text { Description }\end{array}$ & $\begin{array}{c}\text { Benefit vs Risk and } \\
\text { Burdens }\end{array}$ & $\begin{array}{l}\text { Methodological Quality of } \\
\text { Supporting Evidence }\end{array}$ & Implications \\
\hline $\begin{array}{l}1 \mathrm{~A} / \text { strong recommenda- } \\
\text { tion, high-quality evidence }\end{array}$ & $\begin{array}{l}\text { Benefits clearly outweigh risk } \\
\text { and burdens, or vice versa }\end{array}$ & $\begin{array}{l}\text { RCTs without important limitations or } \\
\text { overwhelming evidence from observa- } \\
\text { tional studies }\end{array}$ & $\begin{array}{l}\text { Strong recommendation, can apply } \\
\text { to most patients in most circum- } \\
\text { stances without reservation }\end{array}$ \\
\hline $\begin{array}{l}1 \mathrm{~B} / \text { strong recommenda- } \\
\text { tion, moderate quality } \\
\text { evidence }\end{array}$ & $\begin{array}{l}\text { Benefits clearly outweigh risk } \\
\text { and burdens, or vice versa }\end{array}$ & $\begin{array}{l}\text { RCTs with important limitations (incon- } \\
\text { sistent results, methodological flaws, indi- } \\
\text { rect, or imprecise) or exceptionally strong } \\
\text { evidence from observational studies }\end{array}$ & $\begin{array}{l}\text { Strong recommendation, can apply } \\
\text { to most patients in most circum- } \\
\text { stances without reservation }\end{array}$ \\
\hline $\begin{array}{l}1 \mathrm{C} / \text { strong recommenda- } \\
\text { tion, low-quality or very } \\
\text { low-quality evidence }\end{array}$ & $\begin{array}{l}\text { Benefits clearly outweigh risk } \\
\text { and burdens, or vice versa }\end{array}$ & Observational studies or case series & $\begin{array}{l}\text { Strong recommendation but may } \\
\text { change when higher quality evi- } \\
\text { dence becomes available }\end{array}$ \\
\hline $\begin{array}{l}\text { 2A/weak recommendation, } \\
\text { high-quality evidence }\end{array}$ & $\begin{array}{l}\text { Benefits closely balanced with } \\
\text { risks and burden }\end{array}$ & $\begin{array}{l}\text { RCTs without important limitations or } \\
\text { overwhelming evidence from observa- } \\
\text { tional studies }\end{array}$ & $\begin{array}{l}\text { Weak recommendation, best action } \\
\text { may differ depending on circum- } \\
\text { stances or patients' or societal } \\
\text { values }\end{array}$ \\
\hline $\begin{array}{l}2 \mathrm{~B} / \text { weak recommendation, } \\
\text { moderate-quality evidence }\end{array}$ & $\begin{array}{l}\text { Benefits closely balanced with } \\
\text { risks and burden }\end{array}$ & $\begin{array}{l}\text { RCTs with important limitations (incon- } \\
\text { sistent results, methodological flaws, indi- } \\
\text { rect, or imprecise) or exceptionally strong } \\
\text { evidence from observational studies }\end{array}$ & $\begin{array}{l}\text { Weak recommendation, best action } \\
\text { may differ depending on circum- } \\
\text { stances or patients' or societal } \\
\text { values }\end{array}$ \\
\hline $\begin{array}{l}2 \mathrm{C} / \text { weak recommendation, } \\
\text { low-quality or very low- } \\
\text { quality evidence }\end{array}$ & $\begin{array}{l}\text { Uncertainty in the estimates } \\
\text { of benefits, risks, and burden; } \\
\text { benefits, risk, and burden may } \\
\text { be closely balanced }\end{array}$ & Observational studies or case series & $\begin{array}{l}\text { Very weak recommendations; } \\
\text { other alternatives may be equally } \\
\text { reasonable }\end{array}$ \\
\hline
\end{tabular}

Adapted from Guyatt $\mathrm{G}$ et al. Grading strength of recommendations and quality of evidence in clinical guidelines. Report from an American College of Chest Physicians task force. Chest 2006; 129:174-181 (46). 


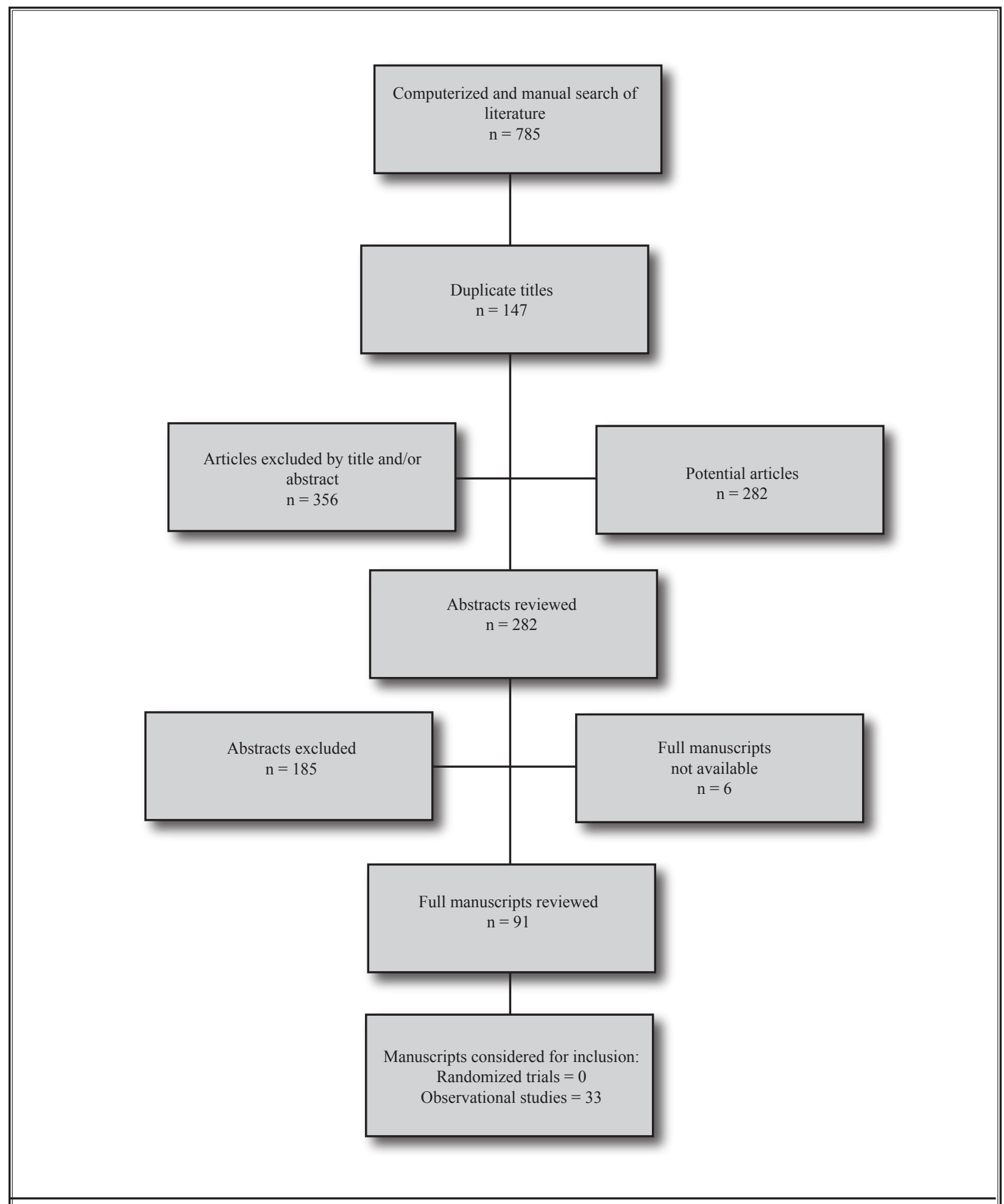

Fig. 1. The flow diagram illustrating literature search for lumbar laser disc decompression. 
Table 3. Reasons for exclusion of observational studies.

\begin{tabular}{|l|l||}
\hline Study & Reason for Exclusion \\
\hline Gevargez et al (47) & $<50$ patients (26 patients) \\
\hline Ohnmeiss et al (48) & $<50$ patients (41 patients) \\
\hline Davis (49) & $<50$ patients (40 patients) \\
\hline Steiner et al (51) & Short-term follow-up with $<50$ patients (7 patients) \\
\hline Schatz \& Talalla (54) & Short-term follow-up with $<50$ patients (14 patients) \\
\hline Simons et al (56) & Short-term follow-up with $<50$ patients \\
\hline Agarwal (60) & $<50$ patients (36 patients) \\
\hline Tassi (66) & Preliminary report of Tassi (72) \\
\hline Lee et al (68) & Endoscopic diskectomy $<50$ patients \\
\hline Tonami et al (69) & Short-term follow-up \\
\hline McMillan et al (70) & Short-term follow-up with $<50$ patients \\
\hline Tonami et al (72) & Complication - osteogenesis of vertebral body \\
\hline Plancarte \& Calvillo (73) & Complication - CRPS Type II \\
\hline Quigley et al (74) & Basic science in-vitro study \\
\hline Savitz et al (75) & Endoscopic surgery \\
\hline Yonezawa et al (76) & Basic science study \\
\hline Taşdemiroğlu et al (77) & Spondylodiscitis - review of reports of complications \\
\hline Choy (78) & Review of device and procedure \\
\hline Casper et al (79) & Description of evolution \\
\hline
\end{tabular}

agement of painful degenerative disc disease with or without associated disc prolapse. Nonendoscopic PLDD was performed under x-ray control via the posterolateral approach in 576 patients. All patients with chronic back pain who had reproduced pain during discography of a nature, pattern, and distribution similar to what they experienced normally were included in the study. Magnetic resonance which confirmed stenosis and sequestrated discs, and patients with acute neurological findings were excluded from the study. Laser disc decompression was done using the KTP532 wavelength. The functional outcome was assessed prospectively using the Oswestry Disability Index. Clinical benefit was considered significant in those patients with a percentage change in the index of $\geq$ or $=50 \%$ at review 3-9 years (mean, 5.33 years) following surgery. A total of $52 \%$ of patients demonstrated a sustained significant clinical benefit, with an additional $21 \%$ in whom functional improvement was noted. Cohort integrity was $67 \%$. They concluded that long-term benefit of the laser disc decompression for disc protrusion suggests a mechanism other than principally mechanical as a cause of chronic back and sciatic pain. It may suggest that efficacy occurs by reduction in the intradiscal production of irritative products and by an effect upon discal and annular neoneuralization. The sustained nature of the benefit after long-term preoperative symptoms (mean 4.7 years) rules out any placebo effect. They recommended that selection should be restricted to patients without significant lateral recess stenosis, retrolisthesis, or olisthesis of $\geq 3 \mathrm{~mm}$, significant dorsal or foraminal osteophytosis, extrusion, or sequestration.

Knight and Goswami (64) provided 3-year followup. Cohort integrity was $67 \%$, even then, it is significant. The report stated that a total of $56 \%$ of these patients achieved more than $50 \%$ of the preoperative rehabilitative objectives, on the patient target achievement scores these were considered to be successes and another $12 \%$ were satisfied with the targets achieved. The emphasis on patient selection cannot be underscored. The authors also cautioned that an ideal candidate with predominat sciatic pain of anatomic dermatomal distribution, without significant spondylosis or facet osteoarthritis and ample bony canal, is relatively rare to find in most back pain referral centers $(80,81)$. The authors also described that there are further complicating factors such as comorbid depression, issues related to compensation. All in all it appears that the long-term follow-up of patients with lumbar disc dis- 
Table 4. Methodological assessment of observational studies evaluating the effectiveness of laser disc decompression.

\begin{tabular}{|c|c|c|c|c|c|c|c|c|}
\hline CRITERION & $\begin{array}{c}\text { Weighted } \\
\text { Score } \\
\text { (points) }\end{array}$ & $\begin{array}{c}\text { Casper } \\
\text { et al } \\
(61)\end{array}$ & $\begin{array}{l}\text { Siebert } \\
\text { et al } \\
(59)\end{array}$ & $\begin{array}{c}\text { Senel } \\
\text { et al } \\
(63)\end{array}$ & $\begin{array}{c}\text { Knight \& } \\
\text { Goswami } \\
\text { (64) }\end{array}$ & $\begin{array}{c}\text { Bosacco } \\
\text { et al } \\
(52)\end{array}$ & $\begin{array}{l}\text { Choy } \\
(53)\end{array}$ & $\begin{array}{l}\text { Zhao } \\
\text { et al } \\
(67)\end{array}$ \\
\hline 1. Study Question & 2 & 2 & 2 & 2 & 2 & 2 & 2 & 2 \\
\hline - Clearly focused and appropriate question & & & & & 2 & & & \\
\hline 2. Study Population & 8 & 5 & 4 & 4 & 5 & 5 & 5 & 5 \\
\hline - Description of study population & 5 & 5 & 4 & 4 & 5 & 5 & 5 & 5 \\
\hline - Sample size justification & 3 & - & - & - & - & - & - & - \\
\hline 3. Comparability of Subjects & 22 & 11 & 5 & 6 & 11 & 14 & 11 & 17 \\
\hline - Specific inclusion/exclusion criteria for all groups & 5 & 5 & 3 & 3 & 5 & 5 & 5 & 5 \\
\hline - Criteria applied equally to all groups & 3 & 3 & 2 & 3 & 3 & 3 & 3 & 3 \\
\hline $\begin{array}{l}\text { - Comparability of groups at baseline with regard } \\
\text { to disease status and prognostic factors }\end{array}$ & 3 & - & - & - & - & 3 & - & 3 \\
\hline $\begin{array}{l}\text { - Study groups comparable to non-participants } \\
\text { with regard to confounding factors }\end{array}$ & 3 & 3 & - & - & - & - & 3 & 3 \\
\hline - Use of concurrent controls & 5 & - & - & - & - & - & - & - \\
\hline $\begin{array}{l}\text { - Comparability of follow-up among groups at } \\
\text { each assessment }\end{array}$ & 3 & - & - & - & 3 & 3 & - & 3 \\
\hline 4. Exposure or Intervention & 11 & 8 & 7 & 7 & 8 & 8 & 8 & 11 \\
\hline - Clear definition of exposure & 5 & 5 & 4 & 4 & 5 & 5 & 5 & 5 \\
\hline - Measurement method standard, valid and reliable & 3 & 3 & 3 & 3 & 3 & 3 & 3 & 3 \\
\hline - Exposure measured equally in all study groups & 3 & - & - & - & - & - & - & 3 \\
\hline 5. Outcome measures & 20 & 15 & 7 & 6 & 15 & 13 & 13 & 20 \\
\hline - Primary/secondary outcomes clearly defined & 5 & 5 & 2 & 3 & 5 & 5 & 5 & 5 \\
\hline $\begin{array}{l}\text { - Outcomes assessed blind to exposure or } \\
\text { intervention }\end{array}$ & 5 & 5 & - & - & - & - & - & 5 \\
\hline $\begin{array}{l}\text { - Method of outcome assessment standard, valid } \\
\text { and reliable }\end{array}$ & 5 & - & - & - & 5 & 3 & 3 & 5 \\
\hline - Length of follow-up adequate for question & 5 & 5 & 5 & 3 & 5 & 5 & 5 & 5 \\
\hline 6. Statistical Analysis & 19 & 13 & 0 & 0 & 10 & 0 & 0 & 8 \\
\hline - Statistical tests appropriate & 5 & 5 & - & - & 5 & - & - & 5 \\
\hline - Multiple comparisons taken into consideration & 3 & 3 & - & - & 3 & - & - & 3 \\
\hline $\begin{array}{l}\text { - Modeling and multivariate techniques } \\
\text { appropriate }\end{array}$ & 2 & - & - & - & 2 & - & - & - \\
\hline - Power calculation provided & 2 & - & - & - & - & - & - & - \\
\hline - Assessment of confounding & 5 & 5 & - & - & - & - & - & - \\
\hline - Dose-response assessment if appropriate & 2 & - & - & - & - & - & - & - \\
\hline 7. Results & 8 & 8 & 5 & 4 & 8 & 6 & 6 & 7 \\
\hline $\begin{array}{l}\text { - Measure of effect for outcomes and appropriate } \\
\text { measure of precision }\end{array}$ & 5 & 5 & 2 & 2 & 5 & 3 & 3 & 4 \\
\hline - Adequacy of follow-up for each study group & 3 & 3 & 3 & 2 & 3 & 3 & 3 & 3 \\
\hline 8. Discussion & 5 & 5 & 3 & 3 & 5 & 5 & 5 & 5 \\
\hline $\begin{array}{l}\text { - Conclusions supported by results with possible } \\
\text { biases and limitations taken into consideration }\end{array}$ & & & & & 5 & & & \\
\hline 9. Funding or Sponsorship & 5 & 5 & 5 & 5 & 5 & 5 & 5 & 5 \\
\hline - Type and sources of support for study & & & & & 5 & & & \\
\hline TOTAL SCORE= & 100 & 72 & 38 & 37 & 69 & 58 & 55 & 80 \\
\hline
\end{tabular}


Pain Physician: May/June 2009:12:573-588

Table 4 Continued. Methodological assessment of observational studies evaluating the effectiveness of laser disc decompression

\begin{tabular}{|c|c|c|c|c|c|c|c|c|}
\hline CRITERION & $\begin{array}{c}\text { Weighted } \\
\text { Score } \\
\text { (points) }\end{array}$ & $\begin{array}{l}\text { Tassi } \\
(71)\end{array}$ & $\begin{array}{c}\text { Grönemeyer } \\
\text { et al (65) }\end{array}$ & $\begin{array}{l}\text { Nerubay } \\
\text { et al (57) }\end{array}$ & $\begin{array}{c}\text { Gangi } \\
\text { et al } \\
(50) \\
\end{array}$ & $\begin{array}{c}\text { Ascher } \\
\text { (58) }\end{array}$ & $\begin{array}{l}\text { Botsford } \\
\quad(62)\end{array}$ & $\begin{array}{c}\text { Liebler } \\
(\mathbf{5 5})\end{array}$ \\
\hline 1. Study Question & 2 & 2 & 2 & 2 & 2 & 2 & 2 & 2 \\
\hline \multicolumn{9}{|l|}{ - Clearly focused and appropriate question } \\
\hline 2. Study Population & 8 & 5 & 5 & 5 & 5 & 5 & 5 & 4 \\
\hline - Description of study population & 5 & 5 & 5 & 5 & 5 & 5 & 5 & 4 \\
\hline - Sample size justification & 3 & - & - & - & - & - & - & - \\
\hline 3. Comparability of Subjects & 22 & 15 & 11 & 11 & 6 & 8 & 14 & 3 \\
\hline $\begin{array}{l}\text { - Specific inclusion/exclusion criteria for all } \\
\text { groups }\end{array}$ & 5 & 5 & 5 & 5 & 3 & 5 & 5 & 3 \\
\hline - Criteria applied equally to all groups & 3 & 3 & 3 & 3 & - & - & 3 & - \\
\hline $\begin{array}{l}\text { - Comparability of groups at baseline with } \\
\text { regard to disease status and prognostic factors }\end{array}$ & 3 & 1 & - & - & - & - & - & - \\
\hline $\begin{array}{l}\text { - Study groups comparable to non-partici- } \\
\text { pants with regard to confounding factors }\end{array}$ & 3 & 3 & 3 & 3 & 3 & 3 & 3 & - \\
\hline - Use of concurrent controls & 5 & - & - & - & - & - & - & - \\
\hline $\begin{array}{l}\text { - Comparability of follow-up among groups at } \\
\text { each assessment }\end{array}$ & 3 & 3 & - & - & - & - & 3 & - \\
\hline 4. Exposure or Intervention & 11 & 11 & 11 & 8 & 6 & 11 & 11 & 7 \\
\hline - Clear definition of exposure & 5 & 5 & 5 & 5 & 4 & 5 & 5 & 4 \\
\hline - Measurement method standard, valid and reliable & 3 & 3 & 3 & 3 & 2 & 3 & 3 & 3 \\
\hline - Exposure measured equally in all study groups & 3 & 3 & 3 & - & - & 3 & 3 & - \\
\hline 5. Outcome measures & 20 & 11 & 15 & 13 & 9 & 10 & 13 & 3 \\
\hline - Primary/secondary outcomes clearly defined & 5 & 3 & 5 & 5 & 2 & 3 & 4 & 2 \\
\hline $\begin{array}{l}\text { - Outcomes assessed blind to exposure or } \\
\text { intervention }\end{array}$ & 5 & - & - & - & - & - & - & - \\
\hline $\begin{array}{l}\text { - Method of outcome assessment standard, } \\
\text { valid and reliable }\end{array}$ & 5 & 3 & 5 & 3 & 2 & 2 & 4 & - \\
\hline - Length of follow-up adequate for question & 5 & 5 & 5 & 5 & 5 & 5 & 5 & 1 \\
\hline 6. Statistical Analysis & 19 & $\mathbf{0}$ & 13 & $\mathbf{0}$ & $\mathbf{0}$ & $\mathbf{0}$ & $\mathbf{0}$ & $\mathbf{0}$ \\
\hline - Statistical tests appropriate & 5 & - & 5 & - & - & - & - & - \\
\hline - Multiple comparisons taken into consideration & 3 & - & 3 & - & - & - & - & - \\
\hline $\begin{array}{l}\text { - Modeling and multivariate techniques } \\
\text { appropriate }\end{array}$ & 2 & - & - & - & - & - & - & - \\
\hline - Power calculation provided & 2 & - & - & - & - & - & - & - \\
\hline - Assessment of confounding & 5 & - & 5 & - & - & - & - & - \\
\hline - Dose-response assessment if appropriate & 2 & - & - & - & - & - & - & - \\
\hline 7. Results & 8 & 7 & 8 & 6 & 6 & 4 & 8 & 3 \\
\hline $\begin{array}{l}\text { - Measure of effect for outcomes and appro- } \\
\text { priate measure of precision }\end{array}$ & 5 & 4 & 5 & 3 & 3 & 2 & 5 & 2 \\
\hline - Adequacy of follow-up for each study group & 3 & 3 & 3 & 3 & 3 & 2 & 3 & 1 \\
\hline 8. Discussion & 5 & 5 & 5 & 5 & 3 & 5 & 5 & 3 \\
\hline \multicolumn{9}{|l|}{$\begin{array}{l}\text { - Conclusions supported by results with possible } \\
\text { biases and limitations taken into consideration }\end{array}$} \\
\hline 9. Funding or Sponsorship & 5 & 5 & 5 & 5 & 5 & 5 & 5 & 5 \\
\hline \multicolumn{9}{|l|}{ - Type and sources of support for study } \\
\hline TOTAL SCORE $=$ & 100 & 61 & 75 & 55 & 42 & 50 & 63 & 30 \\
\hline
\end{tabular}

Adapted and modified from West S et al. Systems to Rate the Strength of Scientific Evidence, Evidence Report, Technology Assessment No. 47. AHRQ Publication No. 02-E016 (17). 
Percutaneous Lumbar Laser Disc Decompression

Table 5. Results of percutaneous disc decompression with laser assisted disc removal

\begin{tabular}{|c|c|c|c|c|c|}
\hline Study & Study Characteristics & $\begin{array}{l}\text { Methodological } \\
\text { Quality Scoring }\end{array}$ & $\begin{array}{l}\text { Number of } \\
\text { Participants }\end{array}$ & Pain Relief & Results \\
\hline Knight \& Goswami (64) & $\mathrm{O}$ & 69 & 576 & $56 \%$ & $\mathrm{P}$ \\
\hline Bosacco et al (52) & $\mathrm{O}$ & 58 & 63 & $66 \%$ & $\mathrm{P}$ \\
\hline Choy (53) & $\mathrm{O}$ & 55 & 518 & $75 \%$ & $\mathrm{P}$ \\
\hline Zhao et al (67) & $\mathrm{O}$ & 80 & 139 & $82 \%$ & $\mathrm{P}$ \\
\hline Tassi (71) & $\mathrm{O}$ & 61 & 419 & $84 \%$ & $\mathrm{P}$ \\
\hline Grönemeyer et al (65) & $\mathrm{O}$ & 75 & 200 & $73 \%$ & $\mathrm{P}$ \\
\hline Nerubay et al (57) & $\mathrm{O}$ & 55 & 50 & $74 \%$ & $\mathrm{P}$ \\
\hline Ascher (58) & $\mathrm{O}$ & 50 & 90 & $74 \%$ & $\mathrm{P}$ \\
\hline Botsford (62) & $\mathrm{O}$ & 63 & 292 & $75 \%$ & $\mathrm{P}$ \\
\hline Casper et al (61) & $\mathrm{O}$ & 72 & 100 & $87 \%$ & $\mathrm{P}$ \\
\hline
\end{tabular}

$\mathrm{O}=$ observational; $\mathrm{P}=$ positive; $\mathrm{N} / \mathrm{A}=$ not applicable.

ease with contained disc herniation and laser disc ablation, based on this study, provides an initially gratifying result, but the results deteriorate over a period of time. Based on the results of this study the majority of the deterioration occurred in the first and second year. They also reported that results were less gratifying in patients who had previous open surgical intervention. They postulated that with the laser disc ablation they failed to adequately address secondary inflammatory processes in the disc. They reported progressive clinical deterioration secondary to further reduction in disc height in $17 \%$ of the patients who were subsequently treated with endoscopic laser foraminoplasty with success. They also reported 4 patients developing aseptic discitis with increased pain and muscular spasm. Additional disc prolapse occurred at the same level in $2 \%$ of the patients.

Bosacco et al (52) sought to evaluate laser disc decompression with the KTP 532 laser, used in conjunction with a percutaneous technique, in contained, small to moderately sized lumbar disc herniation. Sixty-three patients who had a contained herniated nucleus pulposus (HNP) and underwent PLDD were prospectively studied. Sixty-one were available for follow-up. Access to the disc space was attained with an 18-gauge probe, followed by dilating cannulas guided with an image intensifier. Discography was not performed. The power was set at $10 \mathrm{~W}$, and laser pulses were delivered for 0.2 seconds, with an interval of 0.5 seconds. A total of $1250 \mathrm{~J}$ was delivered to the disc space. The average follow-up was 31.75 months (range 20 to 45 months). Overall, 44 patients (72\%) achieved relief of radicular pain and 33 patients $(54 \%)$ achieved relief of low back pain. Thirty-six of 61 patients $(59 \%)$ returned to work by postoperative week 4. Fourteen patients failed treatment, experiencing persistent symptoms (with scores on the Andrews and Lavyne rating scale of $\leq 3$ ). In this study group, optimal results were obtained when symptoms were treated within one-year of presentation. Results from a historical control group are provided for comparison. These authors (52) provided functional results with laser discectomy as well as open discectomy. Based on the results, $85 \%$ of the patients with open discectomy showed good to excellent pain relief, whereas $66 \%$ of patients with laser discectomy showed good to excellent results. They reported only one minor complication involving a single patient who had acute urinary retention and reflex ileus, requiring admission to the hospital for a period of 5 days, 1 week after the laser discectomy procedure. They were not quite sure if this was due to the procedure or the narcotic medication, however, there were no complications involving infection, hematoma, neurologic injury, myelitis, or great vessel disease. In this study, they were able to compare results of laser discectomy with results of open lumbosacral discectomy. However, open surgical results were superior. All other factors have not been evaluated. Based on the results of 1992 and 1993 reports, the hospital costs for percutaneous laser discectomy were $\$ 3,720$ compared to $\$ 10,600$ for open discectomy. Fur- 
ther, if they excluded the compensation patients, the success rate would have increased to $76 \%$. In previously reported data from the same institution the open surgical treatment of lumbar disc disease in a group of city workers' compensation patients resulted in a dismal $80 \%$ rate of permanent disability (82). Further, at the time of publication of Bosacco et al's (52) manuscript, it was a common observation among spinal surgeons that success rates in workers' compensation cases do not keep pace with those in non-compensation circumstances (83-85).

Choy et al (53) conducted a non-randomized, nonblinded study in male and female patients with symptomatic, image-documented intervertebral herniated discs in a 12-year period using PLDD as the only treatment modality. The author's own series consists of 752 intervertebral discs in 518 patients over a period of 12 years. The overall success rate ranged from $75 \%$ to $89 \%$ with a complication rate of less than $1 \%$. They concluded that PLDD has proven to be safe and effective. It is minimally invasive, is performed in an outpatient setting, requires no general anesthesia, results in no scarring or spinal instability, reduces rehabilitation time, is repeatable, and does not preclude open surgery should that become necessary.

Zhao et al (67) evaluated 173 patients with lumbar disc herniations by PLDD. In a non-randomized concurrent controlled trial, 173 patients (101 males and 72 females aged from 18 to 75 years) received PLDD from July 1998 to August 2002 and were followed up for over one year. They divided 173 patients into 2 groups: good indication group (Group $A, n=139$ ) and poor indication group (Group $B, n=34$ ). In addition, Group $B$ was further divided into extrusion group (Group B1 8 patients), lumbar canal stenosis group (Group B2 15 patients), and other conditions group (Group B3 11 patients). Outcome measurements included VAS and modified Macnab criteria, with a primary objective of the degree of pain relief and function. In Group A, excellent results were seen in 63 cases, good in 51 cases, fair in 20 cases, and poor in 5 cases, with $82 \%$ excellent and good rates. The excellent and good rate in Group B was $55.9 \%$. There was a significant difference between Group A and Group B ( $\chi 2=10.38, P<0.05)$. They concluded that PLDD is a convenient, safe, and reliable procedure in treating lumbar disc herniation because of its high success rate, satisfactory results, and fewer complications, and proper selection of indications helps improve the curative effects of lumbar disc herniation.
Zhao et al (67) utilized independent evaluation; but more importantly, they isolated the patients with appropriate indications and without appropriate indications. Consequently, the results were that the excellent and good rate was only $56 \%$ for poor indication good, whereas it was $82 \%$ for the good indication group. Further, the excellent and good rate in other conditions was only $36 \%$. Consequently, appropriately selecting patients can improve the effect of curing prolapse of lumbar intervertebral disc. Further, they indicated that herniation is possible when lumbar disc projection is greater than $0.6 \mathrm{~mm}$, because it may not be differentiated well on MRI, resulting in poor outcomes. In this study the results were similar for patients based on the size of the lumbar disc herniation, but no definite conclusions can be reached because of the small number of cases. They recommended an MRI examination before operation for careful imaging observation to correctly differentiate extrusion from herniation, and fragmented or free nucleus pulposus, because the latter are not indications for percutaneous laser discectomy.

Tassi (71) analyzed the neurosurgical results of 500 patients treated with microdiscectomies and 500 patients treated with PLDD. Patients with herniated discs were treated by microdiscectomy $(n=500)$ according to the Caspar technique, and patients with discogenic pain were treated with PLDD $(n=500)$ according to the Choy technique. The inclusion and exclusion criteria were the same for both groups of patients. Age, gender distribution, multiple levels involved, and associated pathologies were not statistically different. The results were evaluated for both groups with the MacNab criteria. The follow-up period was 2 years (+/-1 year). In the microdiscectomy group, $85.6 \%$ of patients $(n=428)$ had a good or excellent outcome; in the PLDD group, 83.8\% of patients ( $n=419)$ had a good or excellent outcome. Complications occurred in $2.2 \%(n=11)$ of the microdiscectomy group and in $0 \%$ of the PLDD group. They concluded that the analysis of results for the 2 groups supports the conclusion that PLDD is a safe, minimally invasive, and strong alternative treatment to microdiscectomy in patients affected by herniated discs.

Grönemeyer et al (65) sought to describe the longterm effect in 200 patients treated with image-guided PLDD for herniated lumbar disks. The follow-up was over a period of $4+/-1.3$ years. Treatments were carried out under $\mathrm{CT} /$ fluoroscopic guidance with local anesthesia on an outpatient basis with an Nd:YAG laser of $1064 \mathrm{~nm}$. At follow-up, back pain was eliminated or 
reduced in $73 \%$ of the patients. Regarding sensorimotor impairment, PLDD had a positive effect on $74 \%$ of the patients. In the majority of patients, the number of sick days and consumption of pain medication was reduced. In one patient, diskitis occurred as a complication of PLDD. They concluded that image-guided PLDD is an effective and secure method to treat contained herniated lumbar disks.

Nerubay et al (57) reported data from a prospective study of 50 patients with low back and radicular pain caused by an L4-L5 protruded disc treated by percutaneous laser nucleolysis with a carbon dioxide laser. The follow-up ranged from 2 to 5 years, and all the patients were evaluated clinically and by imaging with CT scans and MRI before and after the procedure. According to the MacNab criteria, $74 \%$ of the patients had excellent or good results and $26 \%$ had fair or poor results. They concluded that the laser disc decompression opens up new options in the treatment of discogenic pain, but in their opinion was still an experimental procedure.

Casper et al (61) reported results of a clinical trial of laser disc decompression with a 2-year follow-up. They selected 100 patients based on strict criteria including failure to respond to conservative management. However, all the patients did not undergo fluoroscopically directed epidural injections. Patients with lateral recess or central stenosis, sequestered discs, or predominately scar tissue from a previous discectomy were not considered candidates for laser discectomy. They performed laser discectomy under fluoroscopy with Holmium: YAG laser. An independent interviewer via direct telephone communication carried out evaluations at one week, 3 months, 6 months, one year, and 2 years. The ratings were based on $\mathrm{McNab}$ criteria. At 2 years, a success rate of $86.9 \%$ was achieved. Further, for patients requiring an additional laser discectomy procedure results at 6-month follow-up yielded a success rate of $80 \%$. Nineteen patients out of the 100 within the study were recommended for open laminectomy by a neurosurgeon or orthopedic surgeon. The recommendations were made independent from the authors, and prior to consideration of laser discectomy, patients subsequently elected to undergo laser discectomy. Of these patients, $84 \%$ responded with a successful result. In this study the results were similar at one- and 2-year follow-up without any deterioration in the relief. The findings of this study suggested that laser discectomy provides a safe and efficacious method of treatment for patients with non-sequestered, herniated nucleus pulposus previously unresponsive to con- servative treatment. Further, this study showed that the numbers of discs treated were not an independent predictor of outcomes, i.e, there were similar results in patients with single level disc herniation as well as multiple level herniations. The results also showed that previous surgery did not impede the results with $88 \%$ of patients showing a successful outcome.

\section{Complications and Side Effects}

Complications of percutaneous discectomy laser can be divided into intraoperative and postoperative categories (86-89). Ohnmeiss et al (48) in a series of 164 laser discectomies, reported the tip of the instrument bent in one case, 12 patients complained of postoperative dermatomal dysesthesia, which resolved in 5 cases, and 2 patients had signs of reflex sympathetic dystrophy. Mayer et al (86) in a retrospective analysis of 658 cases treated at 9 different centers observed $1.1 \%$ intraoperative complications and $1.5 \%$ postoperative complications. They reported for radicular deficits in 4 patients $(0.5 \%)$, L5 nerve root injury in 3 cases, vascular injuries in 2 cases, sigmoid artery injury in one patient, anomalous iliolumbar artery injury in one patient, and transverse process injury in one patient. In a report of 10 cases, complications were present in $1.5 \%$ of the total number of cases, which were reported to have spondylodiscitis (87). In another report, after PLDD a patient developed a subacute cauda equina syndrome (88).

The most frequently described complication of PLDD is spondylodiscitis both aseptic and septic $(50,51,53,54,58,59,64)$. The reported frequency of discitis varies from $0 \%(48,52,57,60)$ to $1.2 \%(50)$. Aseptic discitis is the result of heat damage to either the disc or the adjacent vertebral endplates (89). Septic discitis also can occur. A special complication occurs with a $\mathrm{CO} 2$ laser for PLDD with delivering the laser beam through a metal cannula, 4 cases of thermal nerve root damage occurred due to heating of this cannula, presenting a total complication frequency of $8 \%$ (57). Epidural fibrosis also has been reported following percutaneous disc decompression with coblation technology (90).

\section{Level of Evidence}

The indicated level of evidence based on USPSTF criteria (45) is II-2 for short- and long-term relief.

\section{Recommendations}

The recommendation based on Guyatt et al's (46) criteria is $1 \mathrm{C} /$ strong recommendation. 


\section{Discussion}

This systematic review evaluated the role of lumbar disc decompression with automated percutaneous laser discectomy. The present evaluation indicates evidence of II-2 for short- and long-term relief with percutaneous laser discectomy with 1 C/strong recommendation.

In percutaneous laser disc discectomy, or PLDD, laser energy is used to reduce pressure by vaporizing a small volume of the nucleus pulposus, which reduces the pressure between the nucleus pulposus and the peridiscal tissue causing retraction of the herniation away from the nerve root. The systematic review by Gibson and Waddell (5) concluded that clinical outcomes following laser discectomy are at best fair and certainly worse than after microdiscectomy, although the importance of patient selection is important. The evidence for laser discectomy comes from multiple observational studies $(52,53,57,58,61,62,64,65,67,71)$. Overall, a number of patients were evaluated with relief variable from $56 \%$ to $87 \%$ with an average relief of $72 \%$ followed for one-year and the sample size of at least 50 patients.

Even though, conclusive evidence is lacking, randomized trials do not exist, and procedures are labeled as experimental (5), intradiscal therapies and percutaneous mechanical disc decompression techniques continue to increase (91-95). At present, it is believed the potential medical and economic benefits of PLDD are too high to justify discarding it as experimental or ineffective on the sole basis of insufficient scientific proof (8). Well-designed research of sufficient scientific strength, comparing PLDD to both conventional and minimally invasive surgery and conservative management of lumbar disc herniation, is needed to determine whether PLDD deserves a prominent place in the treatment arsenal for lumbar disc herniation. Based on the present evidence it appears that PLDD is equivalent to automated percutaneous lumbar discectomy (32) and superior to coblation and Dekompressor technology $(33,34)$.

The idea of using laser in the treatment of lumbar disc herniations arose in the early 1980 s (8). After a series of in vitro experiments, Choy and colleagues performed the first PLDD on a human patient in February 1986 (96). The U.S. Food and Drug Administration approved PLDD in 1991. By 2002, over 35,000 PLDDs had been performed worldwide (97). The treatment principle of PLDD is based on the concept of the intervertebral disc being a closed hydraulic system. This system consists of the nucleus pulposus, containing a large amount of water, surrounded by the inelastic annulus fibrosis. An increase in water content of the nucleus pulposus leads to a disproportionate increase of intradiscal pressure. In vitro experiments have shown that an increase of intradiscal volume of only $1.0 \mathrm{~mL}$ causes the intradiscal pressure to rise by as much $312 \mathrm{kPa}$ or $2340 \mathrm{mmHg}$ (96). On the other hand, a decrease of intradiscal volume causes a disproportionately large decrease intradiscal pressure. A reduction of intradiscal pressure causes the herniated disc material to recede toward the center of the disc, thus leading to reduction of nerve root compression and relief of radicular pain. In PLDD, this mechanism is exploited by application of laser energy to evaporate water in the nucleus pulposus. The evaporation of water and the increase in temperature causes protein denaturation and subsequent renaturation, causing a structural change of nucleus pulposus, limiting its capability to attract water and therefore leading to a permanent reduction of intradiscal pressure by as much as $57 \%(96)$.

Ten clinical studies $(52,53,57,58,61,62,64,65,67$ ,71) were included in this systematic review, representing a total of 2447 patients. Studies were only included if they met inclusion criteria. Schenk et al (8) included 16 clinical studies representing a total of 1,579 patients. However, since it was a narrative review, the criteria were different. They included studies only if they provided enough information on techniques used in procedure (laser type, parameters used, etc.) and no additional techniques such as endoscopy were used. In this systematic review we also excluded if endoscopy was used except with LASE. Schenk et al (8) also included only trials when they addressed the outcome of PLDD. In the present systematic review and the review by Schenk et al (8) the basic technique of PLDD appears to be the same for all trials. However, in the different studies, while basic principles remain the same, it appears there is a considerable degree of variation in the way PLDD is performed. Differences can be found in the choice of laser type and laser parameters used. While most studies used fluoroscopy some also used additional $\mathrm{CT}$ imaging or even MR imaging.

The inclusion and exclusion criteria used within the different studies showed similarities. The presence of radiologically confirmed herniated disc with corresponding disc with corresponding radicular symptoms was required in all studies for a patient to qualify 
for inclusion. Further, patients with severe neurological symptoms were excluded $(50,55,56,60,61,64,67)$. The majority of the studies considered disc extrusion or sequestered herniation as exclusion criteria and required contained herniations to qualify for the procedure.

Schenk et al (8) reported success rates in the larger studies varying from $75 \%$ (with $95 \% \mathrm{Cl}$ of $69 \%$ to $81 \%$ ) (58) to $87 \%$ (with $95 \% \mathrm{Cl}$ of $80 \%$ to $94 \%$ ) (61). Because of insufficient improvement of symptoms or recurrent herniation, $4.4 \%$ (61) to $25 \%$ (58) of patients received additional surgical treatment. In most cases, surgery revealed the presence of free fragments in the spinal canal.

\section{Conclusion}

This systematic review indicated Level II-2 evidence for percutaneous lumbar laser disc decompression with $1 \mathrm{C} /$ strong recommendation. Thus, laser disc decompression may provide appropriate relief in properly selected patients with contained disc herniations.

\section{Acknowledgements}

The authors wish to thank the editorial board of Pain Physician for review and criticism in improving the manuscript; Sekar Edem for assistance in search of literature; and Tonie M. Hatton and Diane E. Neihoff, transcriptionists (Pain Management Center of Paducah), for their assistance in preparation of this manuscript.

\section{References}

1. Mixter W, Barr J. Rupture of the intervertebral disc with involvement of the spinal canal. N Engl J Med 1934; 211:210215.

2. Deyo RA, Gray DT, Kreuter W, Mirza S, Martin BI. United States trends in lumbar fusion surgery for degenerative conditions. Spine 2005; 30:1441-1445.

3. Deyo RA, Mirza SK, Turner JA, Martin BI. Overtreating chronic back pain: Time to back off? J Am Board Fam Med 2009; 22:62-68.

4. Deyo RA, Mirza SK. Trends and variations in the use of spine surgery. Clin Orthop Relat Res 2006; 443:139-146.

5. Gibson JNA, Waddell G. Surgical interventions for lumbar disc prolapse. Cochrane Database Syst Rev 2009; (1): CDo01350.

6. Carragee EJ, Han MY, Suen PW, Kim D. Clinical outcomes after lumbar discectomy for sciatica: The effects of fragment type and anular competence. J Bone Joint Surg Am 2003; 85-A:102108.

7. Dewing CB, Provencher MT, Riffenburgh RH, Kerr S, Manos RE. The outcomes of lumbar microdiscectomy in a young, active population: Correlation by herniation type and level. Spine 2008; 33:3338.

8. Schenk B, Brouwer PA, Peul WC, van Buchem MA. Percutaneous laser disk decompression: A review of the literature. AJNR Am J Neuroradiol 2006; 27:232235 .
9. Percutaneous Discectomy. Washington State Department of Labor and Industries, Office of Medical Director; February 24, 2004.

10. Boswell MV, Trescot AM, Datta S, Schultz DM, Hansen HC, Abdi S, Sehgal N, Shah RV, Singh V, Benyamin RM, Patel VB, Buenaventura RM, Colson JD, Cordner HJ, Epter RS, Jasper JF, Dunbar EE, Atluri SL, Bowman RC, Deer TR, Hansen HC, Staats PS, Smith HS, Burton AW, Kloth DS, Giordano J, Manchikanti L. Interventional techniques: Evidencebased practice guidelines in the management of chronic spinal pain. Pain Physician 2007; 10:7-111.

11. Manchikanti L, Boswell MV, Giordano J. Evidence-based interventional pain management: Principles, problems, potential, and applications. Pain Physician 2007; 10:329-356.

12. Manchikanti L. Evidence-based medicine, systematic reviews, and guidelines in interventional pain management: Part 1: Introduction and general considerations. Pain Physician 2008; 11:161-186.

13. Manchikanti L, Hirsch JA, Smith HS. Evidence-based medicine, systematic reviews, and guidelines in interventional pain management: Part 2: Randomized controlled trials. Pain Physician 2008; 11:713-775.

14. Manchikanti L, Benyamin RM, Helm S, Hirsch JA. Evidence-based medicine, systematic reviews, and guidelines in interventional pain management: Part 3: Systematic reviews and meta-analysis of randomized trials. Pain Physician 2009; 12:35-72.

15. Manchikanti L, Singh V, Smith HS, Hirsch JA. Evidence-based medicine, systematic reviews, and guidelines in interventional pain management: Part 4: Observational studies. Pain Physician 2009; 12:73-108.

16. Koes BW, Scholten RJ, Mens JMA, Bouter LM. Efficacy of epidural steroid injections for low-back pain and sciatica: A systematic review of randomized clinical trials. Pain 1995; 63:279-288.

17. West S, King V, Carey TS, Lohr KN, McKoy N, Sutton SF, Lux L. Systems to Rate the Strength of Scientific Evidence, Evidence Report, Technology Assessment No. 47. AHRQ Publication No. 02E016. Rockville, MD: Agency for Healthcare Research and Quality, 2002. www. thecre.com/pdf/ahrq-system-strength. pdf

18. Manchikanti L, Singh V, Derby R, Schultz DM, Benyamin RM, Prager JP, Hirsch JA. Reassessment of evidence synthesis of occupational medicine practice guidelines for interventional pain management. Pain Physician 2008; 11:393482.

19. Atluri S, Datta S, Falco FJE, Lee M. Systematic review of diagnostic utility and therapeutic effectiveness of thoracic facet joint interventions. Pain Physician 2008; 11:611-629. 
20. Conn A, Buenaventura R, Datta S, Abdi S, Diwan S. Systematic review of caudal epidurals injections in the management of chronic low back pain. Pain Physician 2009; 12:109-135.

21. Parr AT, Diwan S, Abdi S. Lumbar interlaminar epidural injections in managing chronic low back and lower extremity pain: A systematic review. Pain Physician 2009; 12:163-188.

22. Buenaventura R, Datta S, Abdi S, Smith HS. Systematic review of therapeutic lumbar transforaminal epidural steroid injections. Pain Physician 2009; 12:233-251.

23. Benyamin R, Singh V, Parr AT, Conn A, Diwan S, Abdi S. Systematic review of the effectiveness of cervical epidurals in the management of chronic neck pain. Pain Physician 2009; 12:137-157.

24. Helm S, Hayek SM, Benyamin RM, Manchikanti L. Systematic review of the effectiveness of thermal annular procedures in treating discogenic low back pain. Pain Physician 2009; 12:207-232.

25. Falco FJE, Erhart S, Wargo BW, Bryce DA, Atluri S, Datta S, Hayek SM. Systematic review of diagnostic utility and therapeutic effectiveness of cervical facet joint interventions. Pain Physician 2009; 12:323-344.

26. Datta S, Lee M, Falco FJE, Bryce DA, Hayek SM. Systematic assessment of diagnostic accuracy and therapeutic utility of lumbar facet joint interventions. Pain Physician 2009; 12:437460.

27. Epter RS, Helm S, Hayek SM, Benyamin RM, Smith HS, Abdi S. Systematic review of percutaneous adhesiolysis and management of chronic low back pain in post lumbar surgery syndrome. Pain Physician 2009; 12:361-378.

28. Hayek SM, Helm S, Benyamin RM, Singh V, Bryce DA, Smith HS. Effectiveness of spinal endoscopic adhesiolysis in post lumbar surgery syndrome: A systematic review. Pain Physician 2009; 12:419-435.

29. Frey ME, Manchikanti L, Benyamin RM, Schultz DM, Smith HS, Cohen SP. Spinal cord stimulation for patients with failed back surgery syndrome: A systematic review. Pain Physician 2009; 12:379-397.

30. Patel VB, Manchikanti L, Singh V, Schultz DM, Hayek SM, Smith HS. Systematic review of intrathecal infusion systems for long-term management of chronic non-cancer pain. Pain Physician 2009; 12:345-360.

31. Rupert MP, Lee M, Manchikanti L, Datta S, Cohen SP. Evaluation of sacroiliac joint interventions: A systematic appraisal of the literature. Pain Physician 2009; 12:399-418.

32. Hirsch JA, Singh V, Falco FJE, Benyamin RM, Manchikanti L. Automated percutaneous lumbar discectomy for the contained herniated lumbar disc: A systematic assessment of evidence. Pain Physician 2009; 12:601-620.

33. Manchikanti L, Derby R, Benyamin RM, Helm S, Hirsch JA. A systematic review of mechanical lumbar disc decompression with nucleoplasty. Pain Physician 2009; 12:561-572.

34. Singh V, Benyamin RM, Datta S, Falco FJE, Helm S, Manchikanti L. Systematic review of percutaneous lumbar mechanical disc decompression utilizing Dekompressor. Pain Physician 2009;12:589-599.

35. Salaffi F, Stancati A, Silvestri CA, Ciapetti A, Grassi W. Minimal clinically important changes in chronic musculoskeletal pain intensity measured on a numerical rating scale. Eur / Pain 2004; 8:283-291.

36. Farrar JT, Young JP Jr, LaMoreaux L, Werth JL, Poole RM. Clinical importance of changes in chronic pain intensity measured on an 11-point numerical pain rating scale. Pain 2001; 94:149158.

37. Bombardier C. Outcome assessments in the evaluation of treatment of spinal disorders: Summary and general recommendations. Spine 2000; 25:31003103.

38. Manchikanti L, Singh V, Falco FJE, Cash KA, Pampati V. Effectiveness of thoracic medial branch blocks in managing chronic pain: A preliminary report of a randomized, double-blind controlled trial: Clinical trial NCT00355706. Pain Physician 2008; 11:491-504.

39. Manchikanti L, Singh V, Falco FJ, Cash KA, Fellows B. Cervical medial branch blocks for chronic cervical facet joint pain: A randomized double-blind, controlled trial with one-year follow-up. Spine 2008; 33:1813-1820.

40. Manchikanti L, Singh V, Falco FJ, Cash KA, Pampati V. Lumbar facet joint nerve blocks in managing chronic facet joint pain: One-year follow-up of a randomized, double-blind controlled trial: Clinical Trial NCTo0355914. Pain Physician
2008; 11:121-132.

41. Manchikanti L, Cash KA, McManus CD, Pampati V, Smith HS. Preliminary results of randomized, equivalence trial of fluoroscopic caudal epidural injections in managing chronic low back pain: Part 1. Discogenic pain without disc herniation or radiculitis. Pain Physician 2008; 11:785-800.

42. Manchikanti L, Singh V, Cash KA, Pampati V, Damron KS, Boswell MV. Preliminary results of randomized, equivalence trial of fluoroscopic caudal epidural injections in managing chronic low back pain: Part 2. Disc herniation and radiculitis. Pain Physician 2008; 11:801-815.

43. Manchikanti L, Singh V, Cash KA, Pampati V, Datta S. Preliminary results of randomized, equivalence trial of fluoroscopic caudal epidural injections in managing chronic low back pain: Part 3. Post surgery syndrome. Pain Physician 2008; 11:817-831.

44. Manchikanti L, Cash KA, McManus CD, Pampati V, Abdi S. Preliminary results of randomized, equivalence trial of fluoroscopic caudal epidural injections in managing chronic low back pain: Part 4. Spinal stenosis. Pain Physician 2008; 11:833-848.

45. Berg AO, Allan JD. Introducing the third U.S. Preventive Services Task Force. Am J Prev Med 2001; 20:S3-S4.

46. Guyatt G, Gutterman D, Baumann MH, Addrizzo-Harris D, Hylek EM, Phillips B, Raskob G, Lewis SZ, Schünemann $\mathrm{H}$. Grading strength of recommendations and quality of evidence in clinical guidelines. Report from an American College of Chest Physicians Task Force. Chest 2006; 129:174-181.

47. Gevargez A, Groenemeyer DW, Czerwinski F. CT-guided percutaneous laser disc decompression with Ceralas D, a diode laser with 980-nm wavelength and 200-microm fiber optics. Eur Radiol 2000; 10:1239-1241.

48. Ohnmeiss DD, Guyer R, Hochschuler S. Laser disc decompression: The importance of proper patient selection. Spine 1994; 19:2054-2058.

49. Davis JK. Early experience with laser disc decompression. A percutaneous method. J Fla Med Assoc 1992; 79:3739.

50. Gangi A, Dietemann JL, Ide C, Brunner P, Klinkert A, Warter JM. Percutaneous laser disk decompression under CT and fluoroscopic guidance: Indications, 
technique, and clinical experience. $R a$ diographics 1996; 16:89-96.

51. Steiner P, Zweifel K, BotnarR, Schoenenberger AW, Debatin JF, von Schulthess GK, Hodler J. MR guidance of laser disc decompression: Preliminary in vivo experience. Eur Radiol 1998; 8:592-597.

52. Bosacco SJ, Bosacco DN, Berman AT, Cordover A, Levenberg RJ, Stellabotte J. Functional results of percutaneous laser discectomy. Am J Orthop 1996; 25:825-828.

53. Choy DS. Percutaneous laser disc decompression (PLDD): 12 years experience with 752 procedures in 518 patients. J Clin Laser Med Surg 1998; 16:325-331.

54. Schatz SW, Talalla A. Preliminary experience with percutaneous laser disc decompression in the treatment of sciatica. Can J Surg 1995; 38:432-436.

55. Liebler WA. Percutaneous laser disc nucleotomy. Clin Orthop Relat Res 1995; 310:58-66.

56. Simons P, Lensker E, von Wild K. Percutaneous nucleus pulposus denaturation in treatment of lumbar disc protrusions - a prospective study of 50 neurosurgical patients. Eur Spine $J$ 1994; 3:219-221.

57. Nerubay J, Caspi I, Levinkopf M. Percutaneous carbon dioxide laser nucleolysis with 2- to 5-year followup. Clin Orthop Relat Res 1997; 337:45-48.

58. Ascher PW. Laser trends in minimally invasive treatment: Atherosclerosis, disk herniations. J Clin Laser Med Surg 1991; 9:49-57.

59. Siebert WE, Berendsen BT, Tollgaard J. Percutaneous laser disk decompression. Experience since 1989. Orthopade 1996; 25:42-48.

60. Agarwal S. Ho. YAG laser-assisted lumbar disc decompression: A minimally invasive procedure under local anesthesia. Neurol India 2003; 51:35-38.

61. Casper GD, Hartman VL, Mullins LL. Results of a clinical trial of the holmium: YAG laser in disc decompression utilizing a side-firing fiber: A two-year follow-up. Lasers Surg Med 1996; 19:9096.

62. Botsford JA. Radiological considerations: Patient selection for percutaneous laser disc decompression. J Clin Laser Med Surg 1994; 12:255-259.

63. Senel A, Gokyar A, Iyigun O, Cokluk C, Rakunt C, Celik F. Percutaneous lumbar disc decompression with Nd YAG laser. Ondokuz Mayis Universitesi Tip ergisi
1998; 15:221-226.

64. Knight M, Goswami A. Lumbar percutaneous KTP532 wavelength laser disc decompression and disc ablation in the management of discogenic pain. J Clin Laser Med Surg 2002; 20:9-13.

65. Grönemeyer DH, Buschkamp H, Braun M, Schirp S, Weinsheimer PA, Gevargez A. Image-guided percutaneous laser disk decompression for herniated lumbar disks: A 4-year follow-up in 200 patients. J Clin Laser Med Surg 2003; 21:131-138.

66. Tassi GP. Preliminary Italian experience of lumbar spine percutaneous laser disc decompression according to Choy's method. Photomed Laser Surg 2004; 22:439-441.

67. Zhao DQ, Du F, Yang J, Zheng YB. Cohort-controlled study on percutaneous laser decompression in treating lumbar disc herniation. Chin J Clin Rehabil 2005; 9:202-203.

68. Lee SH, Chung SE, Ahn Y, Kim TH, Park JY, Shin SW. Comparative radiologic evaluation of percutaneous endoscopic lumbar discectomy and open microdiscectomy: A matched cohort analysis. Mt Sinai J Med 2006; 73:795-801.

69. Tonami H, Yokota H, Nakagawa T, Higashi K, Okimura T, Yamamoto I, Nishijima Y. Percutaneous laser discectomy: MR findings within the first 24 hours after treatment and their relationship to clinical outcome. Clin Radiol 1997; 52:938-944.

70. McMillan MR, Patterson PA, Parker V. Percutaneous laser disc decompression for the treatment of discogenic lumbar pain and sciatica: A preliminary report with 3-month follow-up in a general pain clinic population. Photomed Laser Surg 2004; 22:434-438.

71. Tassi GP. Comparison of results of 500 microdiscectomies and 500 percutaneous laser disc decompression procedures for lumbar disc herniation. Photomed Laser Surg 2006; 24:694-697.

72. Tonami H, Kuginuki M, Kuginuki Y, Matoba M, Yokota H, Higashi K, Yamamoto I, Nishijima Y. MR imaging of subchondral osteonecrosis of the vertebral body after percutaneous laser diskectomy. AJR Am J Roentgenol 1999; 173:1383-1386.

73. Plancarte R, Calvillo O. Complex regional pain syndrome type 2 (causalgia) after automated laser discectomy. A case report. Spine 1997; 22:459-61.

74. Quigley MR, Maroon JC, Shih T, Elrifai
A, Lesiecki ML. Laser discectomy. Comparison of systems. Spine 1994; 19:319322.

75. Savitz MH, Doughty H, Burns P. Percutaneous lumbar discectomy with a working endoscope and laser assistance. Neurosurg Focus 1998; 4:e9.

76. Yonezawa T, Onomura T, Kosaka R, Miyaji Y, Tanaka S, Watanabe H, Abe Y, Imachi K, Atumi K, Chinzei T, Mabuchi K, Fujimasa I. The system and procedures of percutaneous intradiscal laser nucleotomy. Spine 1990; 15:1175-1185.

77. Ta demiro lu E, Sengöz A, Bagatur E. latrogenic spondylodiscitis. Neurosurg Focus 2004; 16:1-5.

78. Choy DS. Percutaneous laser disc decompression (PLDD) update: Focus on device and procedure advances. J Clin Laser Med Surg 1993; 11:181-183.

79. Casper GD, Hartman VL, Mullins LL. Percutaneous laser disc decompression with the holmium: YAG laser. J Clin Laser Med Surg 1995; 13:195-203.

80. Abramovitz J, Neff S. Lumbar disc surgery: Results of the prospective lumbar discectomy study of the joint section on disorders of the spine and peripheral nerves of the American Association of Neurological Surgeons and the Congress of Neurological Surgeons. Neurosurgery 1991; 29:301-307.

81. Maroon JC, Onik G, Vidovich DV. Percutaneous discectomy for lumbar disc herniation. Neurosurg Clin N Am 1993; 4:125-134.

82. Bosacco SJ. Results of lumbar disc surgery in a compensation population. Orthopaedic Transactions J Bone Joint Surg 1990; 14:3.

83. Frymoyer JW, Matteri RL, Hanley EN, Kuhlmann D, Howe J. Failed lumbar disc surgery requiring second operation. A long-term follow-up study. Spine 1978; 3:7-11.

84. Greenough CG, Fraser RD. The effects of compensation on recovery from low back injury. Spine 1989; 14:947-955.

85. Hirschfeld AH, Behan RC. The accident process. JAMA 1963; 186:193-199.

86. Mayer HM, Brock M, Stern E. Percutaneous endoscopic laser discectomy: Experimental results. In: Percutaneous Lumbar Discectomy. Springer-Verlag, Heidelberg, 1989.

87. Epstein NE. Nerve root complications of percutaneous laser-assisted diskectomy performed at outside institutions: A technical note. J Spinal Disord 1994; 7:510-512. 
88. Epstein NE. Laser-assisted diskectomy performed by an internist resulting in cauda equina syndrome. I Spinal Disord 1999; 12:77-79.

89. Smuck M, Benny B, Han A, Levin J. Epidural fibrosis following percutaneous disc decompression with coblation technology. Pain Physician 2007; 10:691-696.

90. Turgut M. Extensive damage to the end-plates as a complication of laser discectomy. An experimental study using an animal model. Acta Neurochir (Wien) 1997; 139:404-410.

91. Manchikanti L. Medicare in interventional pain management: A critical analysis. Pain Physician 2006; 9:171198.

92. Manchikanti L. The growth of interventional pain management in the new millennium: A critical analysis of utilization in the Medicare population. Pain Physician 2004; 7:465-482.

93. Manchikanti L, Boswell MV. Interventional techniques in ambulatory surgical centers: A look at the new payment system. Pain Physician 2007; 10:627650.

94. Manchikanti L, Giordano J. Physician payment 2008 for interventionalists: Current state of health care policy. Pain Physician 2007; 10:607-626.
95. Manchikanti L, Singh V, Pampati V, Smith HS, Hirsch JA. Analysis of growth in interventional techniques in managing chronic pain in Medicare population: A 10-year evaluation from 1997 to 2006. Pain Physician 2009; 12:9-34.

96. Choy DSJ, Michelsen J, Getrajdman D, Diwan S. Percutaneous laser disc decompression: An update - Spring 1992. J Clin Laser Med Surg 1992; 10:177-184.

97. Choy DSJ. Percutaneous Laser Disc Decompression: A Practical Guide. Springer-Verlag, New York, 2003. 